\title{
EXPLORING SUSTAINABLE PRODUCT DEVELOPMENT PROCESSES FOR A CIRCULAR ECONOMY THROUGH MORPHOLOGICAL ANALYSIS
}

\author{
Diaz Tena, Anna (1); \\ Schoeggl, Josef-Peter (2,3); \\ Reyes, Tatiana (4); \\ Baumgartner, Rupert J. (1,2) \\ 1: University of Graz, Institute of Systems Sciences, Innovation and Sustainability Research, Graz, \\ Austria; \\ 2: University of Graz, Christian Doppler Laboratory for Sustainable Product Management, Graz, \\ Austria; \\ 3: KTH Royal Institute of Technology, Centr
}

\begin{abstract}
Over the last years, academic literature has made significant progress on the development of key concepts, identifying circular product typologies, developing assessment methods, and exploring the synergies with manufacturing trends such as digitalisation or environmental management. Nevertheless, less attention has been paid on describing process model changes necessary for the implementation of circular product development. For this reason, this paper presents the circular Sustainable Product Development (cSPD) morphological field, aimed at providing implementation guidance to business and industry. It describes possible reconfigurations of the Sustainable Product Development (SPD) process model to further integrate circularity R-strategies, design scopes, design guidelines, inter- and intra-organisational actors and criteria for evaluation. With this framework, we intend to identify the most defining parameters in the process model and assign them a discrete number of categorical values so that different combinations explain the generation of prevalent circular product typologies in the manufacturing of durable goods.
\end{abstract}

Keywords: Circular economy, Organisation of product development, Sustainability, Decision making

\author{
Contact: \\ Diaz Tena, Anna \\ University of Graz \\ Institute of System Sciences, Innovation and Sustainability Research \\ Austria \\ anna.diaz-tena@uni-graz.at
}

Cite this article: Diaz Tena, A., Schoeggl, J.-P., Reyes, T., Baumgartner, R. J. (2021) 'Exploring Sustainable Product Development processes for a Circular Economy through Morphological Analysis', in Proceedings of the International Conference on Engineering Design (ICED21), Gothenburg, Sweden, 16-20 August 2021. DOI:10.1017/pds.2021.410 


\section{INTRODUCTION}

Increasing material efficiency is a key opportunity for achieving climate change targets but technological improvements alone have fallen short in compensating increased resource use and pollutant emissions caused by a worldwide growth of consumers' affluence (Wiedmann et al., 2020). Accordingly, ensuring sustainable patterns of both consumption and production has been established as one of the 17 Sustainable Development Goals (SDGs) set by the United Nations in 2015 - SDG 12 Responsible Consumption and Production. Circular economy (CE), a sustainability paradigm that proposes to disrupt the linear take-make-use-dispose consumption patterns by closing, slowing and narrowing material loops (Bocken et al., 2016) is regarded as a means to meeting to SDG 12 (Schroeder et al., 2019). At the micro level, the CE proposes strategies for companies to retain the value of products for as long as possible, following the Inertia principle (Stahel, 2010). Accordingly, CE frameworks describe and rank several value-retention strategies based on their potential for entropy conservation. For instance, the framework proposed by Reike et al. (2018) establishes four main categories of value-retention strategies: absolute value-preservation (R0 Refuse); short valueretention loops (R1 Reduce, R2 Resell/Reuse, R3 Repair); medium-long value-retention loops (R4 Refurbish, R5 Remanufacture, R6 Re-purpose); and long value-retention loops (R7 Recycle, R8 Recover energy and R9 Re-mine).

To meet these strategies, designers and design engineers need to define new attributes that allow products to comply with circular functionalities. Over the last years, sustainable product development researchers have significantly advanced the conceptualisation of products for a $\mathrm{CE}$ with prominent field contributions intended to describe circular product typologies (Bocken et al., 2016; den Hollander et al., 2017), circular design guidelines (Van den Berg and Bakker, 2015; Moreno et al., 2016; Shahbazi and Jönbrink, 2020; Willskytt and Brambila-Macias, 2020) and proposed circular product performance monitoring and evaluation tools (Kjaer et al., 2018; Kravchenko et al., 2019; Niero and Kalbar, 2019; Saidani et al., 2017). Beyond academia, there exist numerous publiclyavailable resources that showcase circular product typologies (Circle Economy, 2021; Ellen MacArthur Foundation, 2021; European Circular Economy Stakeholder Platform, 2021). Some of the above-mentioned value-retention goals, especially those that understand sustainability performance as a technical problem, have been widely pursued by long-standing sustainable design approaches such as eco-design or cradle-to-cradle design (Ceschin and Gaziulusoy, 2016). Nevertheless, absolute value-preservation and shorter value-retention loops ask for understanding $\mathrm{CE}$ as a socio-technical sustainability-oriented transformation and thus, consider innovating in product dimensions that span beyond materials or product architecture (Baldassarre et al., 2020; Diaz et al., 2021). Therefore, the intra-organisational consequences of developing products for a transformative $\mathrm{CE}$ are important. Nevertheless, instances of lack of implementation guidance for companies aiming at developing products for a CE have been reported (Diaz et al., 2021; Dokter et al., 2021; Fernandes et al., 2020).

Due to its creative nature, the product development process is a complex activity, intertwined with cross-functional processes involving by multiple actors, applying different knowledge, using a wide range of methods and tools. In this context, the main objectives of this study are: a) to develop a morphological field to describe Sustainable Product Development for a circular economy (cSPD) with key process parameters and categorical values for each parameter; $b$ ) to reduce the solution space of the morphological field to a limited number of frequently observed process configurations; c) to test the inference capacity of the solution spaces identified and the overall effectiveness of the method in prescribing a cSPD process roadmap to a product development team. The methodological approach taken in this study is based on a morphological analysis (Zwicky, 1967) which is often applied in the exploration of all possible solutions to any type of multi-dimensional, non-quantified complex problem (Álvarez and Ritchey, 2015). Morphological analyses have resulted useful for structuring engineering design activities: they have been applied in Computer-Aided Design (CAD) systems (Belaziz et al., 2000), production systems (Ostertagová et al., 2012), conceptual process planning (Bezerra and Owen, 2000) and studied as a design method per se (Kannengiesser et al., 2013). Within the CE literature, it has been used to identify circular Business Model Innovation patterns (LüdekeFreund et al., 2019; Pieroni et al., 2019). Nevertheless, to the best of authors' knowledge, it has not been used yet to explain process configurations in sustainable product development for a CE (cSPD). With this framework, we intend to advance current implementation guidance to product planners and product managers to plan processes that can capture circularity goals. 


\section{METHODOLOGICAL DEVELOPMENT}

The methodological underpinning of this study is found on the Design Research Methodology (DRM) (Blessing and Chakrabarti, 2009), which provides a generic framework for developing science-based support to design activities through a sequence of descriptive - prescriptive - descriptive research studies. The present paper, which is found in the intersection of the first Descriptive Study (DS - I) and the first Prescriptive Study (PS - I), combines the analysis of the empirical data collected through indepth expert interviews (Diaz et al., 2021) with the synthesis and experience means used to develop and test the inference capacity of the preliminary support.

\subsection{Developing the morphological field}

The function of the present morphological field is to provide an exhaustive inventory of parameters and values to describe all CE-oriented product development processes. For this purpose, a subset of expert interviews (Diaz et al., 2021) was retrieved. The subset focused on 24 instances of R-strategy implementation during the product development process provided by 15 product development experts belonging to manufacturing industries. Six themes were found to be present in all instances and thus, were set as key parameters of the morphological field (Table 1). Insights for each parameter were compiled in range of categorical values, and terminological differences were normalised through reference articles (Table 1).

Table 1. Key parameters identified through thematic analysis of 24 instances of $R$-strategy implementation and reference publications for categorical value standardisation.

$\begin{array}{lc}\begin{array}{l}\text { Key } \\ \text { parameter } \\ \text { R-strategy }\end{array} & \begin{array}{c}\text { Relevance } \\ \text { R-strategies are necessary to identify } \\ \text { value-retention throughout lifecycle } \\ \text { phases and actors }\end{array} \\ \begin{array}{l}\text { Design scope } \\ \text { Transformative CE-oriented product } \\ \text { designs address socio-technical } \\ \text { aspects }\end{array} \\ \begin{array}{l}\text { Design } \\ \text { guidelines }\end{array} & \begin{array}{c}\text { Guidelines need to be used to bridge } \\ \text { the level of abstraction between R- } \\ \text { strategies and product design } \\ \text { activities }\end{array} \\ \begin{array}{l}\text { Lifecycle } \\ \text { stakeholders }\end{array} & \begin{array}{c}\text { New lifecycle stakeholders are } \\ \text { impacted by circular functionalities of } \\ \text { products }\end{array} \\ \begin{array}{l}\text { Cross- } \\ \text { functional } \\ \text { actors }\end{array} & \begin{array}{c}\text { Cross-functional teams are involved } \\ \text { in managing new lifecycle actors }\end{array} \\ \begin{array}{l}\text { Product } \\ \text { evaluation } \\ \text { criteria }\end{array} & \begin{array}{c}\text { Economic, environmental, and social } \\ \text { criteria need to be evaluated together }\end{array} \\ & \text { with the rest of criteria for product } \\ \text { requirements }\end{array}$

Values

10 R-strategy framework (Reike et al., 2018b)

Classification of design problems to be addressed in a CE (Diaz et al., 2021)

(Van den Berg and Bakker, 2015; Ceschin and Gaziulusoy, 2016; Moreno et al., 2016; Shahbazi and Jönbrink, 2020; Willskytt and

Brambila-Macias, 2020)

Actors and system maps (Desai et al., 2017)

Corporate functions on the operational management level (Baumgartner, 2010)

Criteria for optimising sustainability in products and services (Maxwell and Van der Vorst, 2003)

\subsection{Reduction of the solution space provided by the morphological field}

For a morphological field to be informative, it is necessary to identify the compatibility among all values from each of the parameters to establish possible configurations. This is formally done through a cross-consistency assessment (CCA), where all parameter values in the field are compared to one another. By doing this, internally inconsistent configurations are discarded, and the solution space (the subset of all possible configurations) is reduced. Nevertheless, the internal relations among values are implied by logical, empirical and normative constraints placed on them by real-world problems and these determine the important content of the model (Ritchey, 2011). Therefore, the current study has omitted a structured reduction of the solution space through the formal combinatorial properties of the morphological field and focused on identifying the patterns that emerge recurrently from observing 
different instances of cSPD. Each instance was analysed through deductive coding the resulting 24 configurations were compared and grouped based on similarity.

\subsection{Testing the descriptive and prescriptive applications of the morphological field}

A group of six graduate engineers working on a product development project commissioned by a road freight transport component manufacturer was recruited to test the descriptive and prescriptive uses of the morphological field. By descriptive use, it is meant to assess the capacity of the parameters and values present in the morphological field allow to explain any possible cSPD process configuration (completeness). The prescriptive use refers to the inference capacity of the model - given a specific value input, then the solution spaces provide a coherent actionable output (coherence, consistency, clarity and instrumentability). Due to local Covid-19 restrictions, the workshop had to be conducted on-line and virtual canvases (Miro boards) were used as input-output interface. The workshop was composed by 5 exercises covering all parameters from the morphological field. The group was asked to provide input values in each of the exercises and the quality of output values (aligned with a previously identified solution space) was discussed. A summary of the exercises can be found in Table 2.

Table 2. Workshop application of the morphological field. FSSD = Framework for Strategic Sustainable Development; SWOT = Strengths, Weaknesses, Opportunities, Threats.

\begin{tabular}{|c|c|c|c|c|}
\hline Exercise & $\begin{array}{l}\text { Coverage of } \\
\text { parameters }\end{array}$ & Goal & Input & Output \\
\hline $\begin{array}{l}\text { Conceptual } \\
\text { analysis }\end{array}$ & $\begin{array}{l}\text { R-strategy; } \\
\text { Design } \\
\text { scope; } \\
\text { Design } \\
\text { guidelines; }\end{array}$ & $\begin{array}{l}\text { To establish the links between } \\
\text { R-strategies to new circular } \\
\text { design attributes }\end{array}$ & Task & $\begin{array}{r}\text { Circular design } \\
\text { guidelines }\end{array}$ \\
\hline $\begin{array}{l}\text { Lifecycle } \\
\text { stakeholder } \\
\text { map }\end{array}$ & $\begin{array}{l}\text { Lifecycle } \\
\text { stakeholders }\end{array}$ & $\begin{array}{l}\text { To establish the link circular } \\
\text { design attributes to impacted } \\
\text { lifecycle stakeholders }\end{array}$ & $\begin{array}{l}\text { Circular } \\
\text { design } \\
\text { guidelines }\end{array}$ & $\begin{array}{r}\text { Impacted } \\
\text { lifecycle } \\
\text { stakeholders }\end{array}$ \\
\hline $\begin{array}{l}\text { Cross- } \\
\text { functional } \\
\text { stakeholder } \\
\text { map }\end{array}$ & $\begin{array}{l}\text { Cross- } \\
\text { functional } \\
\text { stakeholders }\end{array}$ & $\begin{array}{l}\text { To identify the cross-functional } \\
\text { actors that manage the impacts } \\
\text { on lifecycle stakeholders }\end{array}$ & $\begin{array}{l}\text { Impacted } \\
\text { lifecycle } \\
\text { stakeholders }\end{array}$ & $\begin{array}{r}\text { Influential cross- } \\
\text { functional } \\
\text { stakeholders }\end{array}$ \\
\hline $\begin{array}{l}\text { FSSD } \\
\text { SWOT }\end{array}$ & Evaluation & $\begin{array}{l}\text { To map the sustainability } \\
\text { impacts from new product } \\
\text { attributes }\end{array}$ & $\begin{array}{l}\text { Circular } \\
\text { product } \\
\text { guidelines }\end{array}$ & $\begin{array}{r}\text { Environmental } \\
\text { and social } \\
\text { evaluation }\end{array}$ \\
\hline $\begin{array}{l}\text { Trade-off } \\
\text { identification }\end{array}$ & Evaluation & $\begin{array}{c}\text { To perform a technical } \\
\text { evaluation on circular product } \\
\text { attributes }\end{array}$ & $\begin{array}{l}\text { Circular } \\
\text { product } \\
\text { guidelines }\end{array}$ & $\begin{array}{r}\text { Technical and } \\
\text { economic } \\
\text { evaluation }\end{array}$ \\
\hline
\end{tabular}

\section{RESULTS AND DISCUSSION}

\subsection{Morphological field and process configuration patterns}

The complete morphological field is represented in Figure 1. The header row identifies the parameters and the values for each parameter are displayed in the corresponding column. 


\begin{tabular}{|c|c|c|c|c|c|}
\hline R-strategy (P1) & Design scope (P2) & Design guidelines (P3) & Lifecycle stakeholders (P4) & $\begin{array}{l}\text { Cross-functional actors } \\
\text { (P5) }\end{array}$ & $\begin{array}{l}\text { Evaluation } \\
\text { (P6) }\end{array}$ \\
\hline $\begin{array}{l}\text { Refuse } \\
(1.1)\end{array}$ & $\begin{array}{l}\text { Material } \\
(2.1)\end{array}$ & $\begin{array}{l}\text { Design for sustainability transitions } \\
\text { (3.1) }\end{array}$ & $\begin{array}{l}\text { Market players } \\
(4.1)\end{array}$ & $\begin{array}{l}\text { C-level management } \\
(5.1)\end{array}$ & $\begin{array}{l}\text { Technical } \\
(6.1)\end{array}$ \\
\hline $\begin{array}{l}\text { Reduce } \\
(1.2)\end{array}$ & $\begin{array}{l}\text { Architecture } \\
(2.2)\end{array}$ & $\begin{array}{l}\text { Network design } \\
\text { (3.2) }\end{array}$ & $\begin{array}{l}\text { Suppliers } \\
(4.2)\end{array}$ & $\begin{array}{l}\text { Procurement; } \\
\text { Design and production } \\
\text { (5.2) }\end{array}$ & $\begin{array}{l}\text { Economic } \\
(6.2)\end{array}$ \\
\hline $\begin{array}{l}\text { Resell } \\
(1.3)\end{array}$ & $\begin{array}{l}\text { Service } \\
(2.3)\end{array}$ & $\begin{array}{l}\text { Revenue model design } \\
\text { (3.3) }\end{array}$ & $\begin{array}{l}\text { Shipping and storage; } \\
\text { Dealership; } \\
\text { Concession holders } \\
(4.3)\end{array}$ & $\begin{array}{l}\text { Logistics } \\
(5.3)\end{array}$ & $\begin{array}{l}\text { Environmental } \\
(6.3)\end{array}$ \\
\hline $\begin{array}{l}\text { Repair } \\
(1.4)\end{array}$ & $\begin{array}{l}\text { Revenue model } \\
(2.4)\end{array}$ & $\begin{array}{l}\text { Product-service system design } \\
\text { (PSS design) } \\
\text { (3.4) }\end{array}$ & $\begin{array}{l}\text { Target customers } \\
(4.4)\end{array}$ & $\begin{array}{l}\text { Marketing and sales } \\
(5.4)\end{array}$ & $\begin{array}{l}\text { Social } \\
(6.4)\end{array}$ \\
\hline $\begin{array}{l}\text { Refurbish } \\
\text { (1.5) }\end{array}$ & $\begin{array}{l}\text { Ecosystem } \\
(2.5)\end{array}$ & $\begin{array}{l}\text { Design for multiple life cycles } \\
\text { (3.5) }\end{array}$ & $\begin{array}{l}\text { Local depots; } \\
\text { Local repair services } \\
\text { (4.5) }\end{array}$ & $\begin{array}{l}\text { Fleet management; } \\
\text { Aftersales service; } \\
\text { Maintenance } \\
(5.5)\end{array}$ & \\
\hline $\begin{array}{l}\text { Remanufacture } \\
(1.6)\end{array}$ & & $\begin{array}{l}\text { Design for sustainable use } \\
\text { (3.6) }\end{array}$ & $\begin{array}{l}\text { Local waste; management; } \\
\text { Local dismantlers; } \\
\text { (4.6) }\end{array}$ & $\begin{array}{l}\text { Procurement } \\
(5.6)\end{array}$ & \\
\hline $\begin{array}{l}\text { Repurpose } \\
(1.7)\end{array}$ & & $\begin{array}{l}\text { Design for product life extension } \\
\text { (3.7) }\end{array}$ & & & \\
\hline $\begin{array}{l}\text { Recycle materials } \\
(1.8)\end{array}$ & & $\begin{array}{l}\text { Design for remanufacturing } \\
(3.8)\end{array}$ & & & \\
\hline $\begin{array}{l}\text { Recover energy } \\
\text { (1.9) }\end{array}$ & & $\begin{array}{l}\text { Design for disassembly } \\
\text { (3.9) }\end{array}$ & & & \\
\hline \multirow[t]{2}{*}{$\begin{array}{l}\text { Re-mine } \\
(1.10)\end{array}$} & & $\begin{array}{l}\text { Design for recycling } \\
(3.10)\end{array}$ & & & \\
\hline & & $\begin{array}{l}\text { Design for energy recovery } \\
\text { (3.11) }\end{array}$ & & & \\
\hline
\end{tabular}

Figure 1. Morphological field

Figure 2 describes the patterns observed and the number of times they appeared across the 24 instances of R-strategy implementation. Pattern 6 emerged the most (8 cases) and was linked to design for recycling projects, with implications for products' materials (and indirectly, architecture), DfE-oriented guidelines and evaluation and implications for suppliers and end-of-life managers. Pattern 5 presented the second highest frequency and was linked to reverse logistics projects (4 cases) enabling different R-strategies oriented at the recovery of products' partial or total functionality and thus, the design scope focused on creating the reverse logistics networks around the product and implement architecture changes necessary to facilitate dismantling, with impacts on the revenue model. This involves customers and aftersales management actors. Next to this, Pattern 2 (4 cases) was observed in cases were a reduction of material content or energy use during the use phase was pursued. This posed implications for entire lifecycle actors and affected the materials, the architecture, and the service design. Pattern 4, corresponding to the implementation material passports emerged as well (3 cases), mostly involving architecture changes (modular design) and affecting stakeholders from the entire lifecycle (obtaining information from suppliers to dismantlers). Pattern 1 (3 cases) corresponded to result-oriented PSS and it involved the redesign of intangible product dimensions such as the products' service, revenue models and the ecosystems. This contrasts with Pattern 3 (2 cases), corresponding to product-oriented PSS where mostly tangible changes in architecture were observed. 


\begin{tabular}{|c|c|c|c|c|c|c|c|}
\hline Pattern & Cases & R-strategies & Design scope & Design guidelines & Lifecycle stakeholders & $\begin{array}{c}\text { Cross-functional } \\
\text { teams }\end{array}$ & Evaluation \\
\hline $\begin{array}{l}\text { Pattern } 1 \\
\text { Result-oriented } \\
\text { PSS }\end{array}$ & 3 & $\begin{array}{l}\text { Refuse } \\
\text { Resell/Reuse } \\
\text { Repair }\end{array}$ & $\begin{array}{l}\text { Ecosystem; } \\
\text { Revenue model; } \\
\text { Service }\end{array}$ & $\begin{array}{l}\text { Network design; } \\
\text { Revenue model design; } \\
\text { PSS design }\end{array}$ & $\begin{array}{l}\text { Target customers; } \\
\text { Local depots; } \\
\text { Local repair services; } \\
\text { Local dismantlers; }\end{array}$ & $\begin{array}{l}\text { Management; } \\
\text { Procurement; } \\
\text { Marketing and sales; } \\
\text { Aftersales service; } \\
\text { Maintenance }\end{array}$ & $\begin{array}{l}\text { Technical; } \\
\text { Economic }\end{array}$ \\
\hline $\begin{array}{l}\text { Pattern } 2 \\
\text { Reduce material } \\
\text { and energy }\end{array}$ & 4 & $\begin{array}{l}\text { Refuse } \\
\text { Reduce }\end{array}$ & $\begin{array}{l}\text { Material; } \\
\text { Architecture; } \\
\text { Service }\end{array}$ & $\begin{array}{l}\text { Product life extension; } \\
\text { Design for recycling; } \\
\text { Network design; } \\
\text { Revenue model design; } \\
\text { PSS design }\end{array}$ & $\begin{array}{l}\text { Market players; } \\
\text { Suppliers; } \\
\text { Target customers; } \\
\text { Local depots; } \\
\text { Local repair services } \\
\text { Local waste management }\end{array}$ & $\begin{array}{l}\text { Procurement; } \\
\text { Logistics; } \\
\text { Marketing and sales; } \\
\text { Aftersales service; } \\
\text { Maintenance }\end{array}$ & $\begin{array}{l}\text { Technical; } \\
\text { Economic; } \\
\text { Environmental }\end{array}$ \\
\hline $\begin{array}{l}\text { Pattern } 3 \\
\text { Product-oriented } \\
\text { PSS }\end{array}$ & 2 & Repair & $\begin{array}{l}\text { Architecture; } \\
\text { Service; } \\
\text { Revenue model; } \\
\text { Ecosystem }\end{array}$ & $\begin{array}{l}\text { Revenue model design; } \\
\text { Design for product life } \\
\text { extension }\end{array}$ & $\begin{array}{l}\text { Target customers; } \\
\text { Local depots; } \\
\text { Local repair services }\end{array}$ & $\begin{array}{l}\text { Management; } \\
\text { Marketing and sales; } \\
\text { Aftersales service; } \\
\text { Maintenance }\end{array}$ & $\begin{array}{l}\text { Technical; } \\
\text { Economic }\end{array}$ \\
\hline $\begin{array}{l}\text { Pattern } 4 \\
\text { Material passports }\end{array}$ & 3 & $\begin{array}{l}\text { Repair; } \\
\text { Remanufacture; } \\
\text { Recycle materials }\end{array}$ & Architecture & $\begin{array}{l}\text { Design for remanufacturing; } \\
\text { Design for disassembly; } \\
\text { Design for recycling }\end{array}$ & $\begin{array}{l}\text { Target customers; } \\
\text { Local depots; } \\
\text { Local repair services; }\end{array}$ & $\begin{array}{l}\text { Procurement; } \\
\text { Fleet management; } \\
\text { Aftersales service; } \\
\text { Maintenance }\end{array}$ & $\begin{array}{l}\text { Technical; } \\
\text { Economic }\end{array}$ \\
\hline $\begin{array}{l}\text { Pattern } 5 \\
\text { Reverse logistics }\end{array}$ & 4 & $\begin{array}{l}\text { Refurbish; } \\
\text { Remanufacture; } \\
\text { Repurpose; } \\
\text { Recycle materials }\end{array}$ & $\begin{array}{l}\text { Material; } \\
\text { Architecture; } \\
\text { Service; } \\
\text { Revenue model; } \\
\text { Ecosystem }\end{array}$ & $\begin{array}{l}\text { Network design; } \\
\text { Revenue model design; } \\
\text { Design for disassembly; } \\
\text { Design for recycling; }\end{array}$ & $\begin{array}{l}\text { Target customers; } \\
\text { Local depots; } \\
\text { Local repair services; } \\
\text { Local waste management; } \\
\text { Local dismantlers; }\end{array}$ & $\begin{array}{l}\text { Procurement; } \\
\text { Logistics; } \\
\text { Marketing and sales; } \\
\text { Fleet management; } \\
\text { Aftersales service; } \\
\text { Maintenance }\end{array}$ & $\begin{array}{l}\text { Technical; } \\
\text { Economic; } \\
\text { Environmental; } \\
\text { Social; }\end{array}$ \\
\hline $\begin{array}{l}\text { Pattern } 6 \\
\text { Design for } \\
\text { recycling }\end{array}$ & 8 & $\begin{array}{l}\text { Recycle materials; } \\
\text { Recover energy }\end{array}$ & $\begin{array}{l}\text { Material; } \\
\text { Architecture } \\
\text { Ecosystem }\end{array}$ & $\begin{array}{l}\text { Network design } \\
\text { Design for disassembly; } \\
\text { Design for recycling; } \\
\text { Design for energy recovery }\end{array}$ & $\begin{array}{l}\text { Suppliers; } \\
\text { Target customers; } \\
\text { Local depots; } \\
\text { Local repair services; } \\
\text { Local waste management; } \\
\text { Local dismantlers }\end{array}$ & $\begin{array}{l}\text { Management; } \\
\text { Procurement; }\end{array}$ & $\begin{array}{l}\text { Technical; } \\
\text { Economic; } \\
\text { Environmental }\end{array}$ \\
\hline
\end{tabular}

Figure 2. Process configuration patterns ( $n=24$ cases)

Regarding completeness, the morphological field has been found suitable for explaining all 24 cSPD implementation process observed. The morphological analysis, and the resulting morphological field has provided a useful framework to identify recurring patterns and allows to reason the differences observed across them. Nevertheless, some parameter values (e.g., cross-functional teams) hardly change across the patterns, which means that there is room for further simplification of the morphological field (if several values appear together in all instances, they can be considered as a unique one). This would require a formal CCA analysis. Nevertheless, the morphological analysis has been found useful to systematically compare cSPD process configurations and shows potential to disclose the implementation black box of circular products.

\subsection{Testing the inference capacity of the morphological field}

The product development stage of the team composed by 6 graduate engineer students was found to be at the conceptual phase when the morphological field was tested. The goal of the development project was to substitute a component of a road freight transport vehicle that functioned with a non-renewable energy carrier and design an electrified version of it to increase energy efficiency (Pattern 2). The team was not exposed to any process pattern prior to the workshop. Table 3 presents a comparison between Pattern 2 values and the actual process values devised by the team. The process roadmap row includes the input values from the team and output values provided by the morphological field that were integrated as part of the process by the team (italics). It can be observed that both processes displayed 17 values in common (out of 23) and the systemic implications of the circular product were translated into a process roadmap. In the comparison table (Table 3) it can be observed that the parameter that shows greater variability is "R-strategy". In practice, the numerous theoretical nuances among Rstrategies resulted not informative to devise their operational implications from a product engineering standpoint (identify the design guidelines). Nevertheless, they supported the identification of lifecycle stakeholders. Discussing the design scope was useful to structure an exploration of the systemic implications of the design: the value "material" was not regarded valid for the team. Its consideration in line with Pattern 2 - sparked an important discussion on a potential rebound effect on energy efficiency due to an increase of weight in the component using specific materials. Therefore, Pattern 2 helped devise an unforeseen relevant design scope value and provided valuable output. During the test, it was identified that the connection between lifecycle stakeholders and cross-functional teams could be easily established by identification of tasks - i.e., target customer (lifecycle stakeholder) - market study (task) - marketing team (cross-functional unit). A final remark is the usefulness of the FSSD 
qualitative indicator framework to guide the reasoning of a group of engineers (with no background knowledge on sustainability and no sustainability impact data) on the sustainability assessment and the systemic implications of a new design. Nevertheless, the moderation by a knowledgeable sustainability facilitator to discern the validity of the assumptions behind the reasoning of the group was necessary. The result of the evaluation exercise was a heat map of potential sustainability impacts which should be later verified when data is available.

Table 3. Comparison of parameter values between pattern 2 and the process roadmap configured during the workshop.

\begin{tabular}{|c|c|c|c|c|c|c|}
\hline $\begin{array}{l}\text { Configu- } \\
\text { ration }\end{array}$ & $\begin{array}{c}\text { R- } \\
\text { strategy } \\
(\mathbf{P 1})\end{array}$ & $\begin{array}{c}\text { Design } \\
\text { scope (P2) }\end{array}$ & $\begin{array}{c}\text { Design } \\
\text { guidelines } \\
\text { (P3) }\end{array}$ & $\begin{array}{c}\text { Lifecycle } \\
\text { stakeholder } \\
\text { s (P4) }\end{array}$ & $\begin{array}{c}\text { Cross- } \\
\text { functional } \\
\text { actors (P5) }\end{array}$ & $\begin{array}{r}\mathrm{R} \\
\text { strategy } \\
(\mathbf{P 1})\end{array}$ \\
\hline Pattern 2 & $\begin{array}{l}\text { Refuse; } \\
\text { Reduce }\end{array}$ & $\begin{array}{l}\text { Material; } \\
\text { Architec- } \\
\text { ture; } \\
\text { Service }\end{array}$ & $\begin{array}{c}\text { Product life } \\
\text { extension; } \\
\text { Design for } \\
\text { recycling; } \\
\text { Network } \\
\text { design; } \\
\text { Revenue } \\
\text { model } \\
\text { design; } \\
\text { PSS design }\end{array}$ & $\begin{array}{c}\text { Market } \\
\text { players; } \\
\text { Suppliers; } \\
\text { Target } \\
\text { customers; } \\
\text { Local } \\
\text { depots; } \\
\text { Local repair } \\
\text { services }\end{array}$ & $\begin{array}{l}\text { Procurement; } \\
\text { Logistics; } \\
\text { Marketing } \\
\text { and sales; } \\
\text { Aftersales } \\
\text { service; } \\
\text { Maintenance }\end{array}$ & $\begin{array}{r}\text { Technical } \\
\text { Economic } \\
\text { Environme } \\
\text { nta }\end{array}$ \\
\hline $\begin{array}{l}\text { Process } \\
\text { roadmap }\end{array}$ & $\begin{array}{c}\text { Refuse } \\
\text { Reduce } \\
\text { Repair } \\
\text { Remanufa } \\
\text { c-ture } \\
\text { Recycle }\end{array}$ & $\begin{array}{c}\text { Material; } \\
\text { Architec- } \\
\text { ture; } \\
\text { Service } \\
\text { Ecosystem }\end{array}$ & $\begin{array}{l}\text { Product life } \\
\text { extension; } \\
\text { Revenue } \\
\text { model } \\
\text { design } \\
\text { PSS Design }\end{array}$ & $\begin{array}{c}\text { Suppliers; } \\
\text { Target } \\
\text { customers; } \\
\text { Local waste } \\
\text { managemen } \\
\text { t }\end{array}$ & $\begin{array}{l}\text { Procurement; } \\
\text { Marketing } \\
\text { and sales; } \\
\text { Maintenance }\end{array}$ & $\begin{array}{r}\text { Technical } \\
\text { Economic } \\
\text { Environ- } \\
\text { mental } \\
\text { Socia }\end{array}$ \\
\hline
\end{tabular}

\section{CONCLUSIONS}

This study has used a morphological analysis to structure cSPD processes and derived preliminary process configurations patterns to inform the implementation activities linked to products designed for a circular economy. The morphological field has been built up using primary data (expert interviews describing 24 instances of R-strategy implementation during product development) and secondary data (reference articles for the standardisation of categorical values) and tested with a product development team. The resulting morphological field has found to be complete enough to describe all cSPD processes analysed in this study. A preliminary solution space has been identified based on similarity of value, consisting of 6 process configurations patterns. The discernment between configuration patterns requires further combinatorial formalisation, but the existing solution space has provided close to $75 \%$ value coincidence between the prescribed and an actual process configuration. The morphological field has proved useful to outline a coherent cSPD process roadmap composed by actionable tasks to an engineering team. All in all, the qualitative model present in this study shows preliminary prescriptive capacity, that could be improved by refining terminological differences between literature and practice, improve the user interfaces for providing input and output and linking the process configurations with background documents providing support for the user to complete process tasks.

\section{ACKNOWLEDGEMENTS}

Anna Diaz, Tatiana Reyes and Rupert J. Baumgartner received funding from the European Union's Horizon 2020 research and innovation programme under Marie Sklodowska-Curie grant agreement No. 765198. The financial support to Josef-Peter Schöggl and Rupert J. Baumgartner of the Austrian Federal Ministry for Digital and Economic Affairs, the National Foundation for Research, Technology and Development, and the Christian Doppler Research Association, is gratefully acknowledged. The authors would also like to thank the Centre for ECO2 Vehicle Design at KTH, funded by the Swedish 
Innovation Agency Vinnova, aimed at supporting the development of resource efficient vehicles in a sustainable society.

\section{REFERENCES}

Álvarez, A. and Ritchey, T. (2015), “Applications of General Morphological Analysis”, Acta Morphologica Generalis.

Baldassarre, B., Keskin, D., Diehl, J.C., Bocken, N. and Calabretta, G. (2020), “Implementing sustainable design theory in business practice: A call to action", Journal of Cleaner Production, Elsevier Ltd, Vol. 273, p. 123113.

Baumgartner, R.J. (2010), Nachhaltigkeitsorientierte Unternehmensführung: Modell, Strategien Und Managementinstrumente, Rainer Ham., Mering.

Belaziz, M., Bouras, A. and Brun, J.M. (2000), "Morphological analysis for product design", CAD Computer Aided Design, available at: https://doi.org/10.1016/S0010-4485(00)00019-1.

Van den Berg, M.R. and Bakker, C.A. (2015), "A product design framework for a circular economy”, PLATE (Product Lifetimes And The Environment) Conference Proceedings.

Bezerra, C. and Owen, C.L. (2000), "Evolutionary Structured Planning", Artificial Intelligence in Design '00, available at: https://doi.org/10.1007/978-94-011-4154-3_15.

Blessing, L.T.M. and Chakrabarti, A. (2009), DRM, a Design Research Methodology, DRM, a Design Research Methodology, available at: https://doi.org/10.1007/978-1-84882-587-1.

Bocken, N.M.P., de Pauw, I., Bakker, C. and van der Grinten, B. (2016), "Product design and business model strategies for a circular economy", Journal of Industrial and Production Engineering, available at: https://doi.org/10.1080/21681015.2016.1172124.

Ceschin, F. and Gaziulusoy, I. (2016), "Evolution of design for sustainability: From product design to design for system innovations and transitions", Design Studies, available at: https://doi.org/10.1016/j.destud.2016.09.002.

Circle Economy. (n.d.). "Circle Lab", available at: https://circle-lab.com/.

Desai, A., Lindahl, M. and Widgren, M. (2017), "Actors and System Maps: A Methodology for Developing Product/Service Systems", available at: https://doi.org/10.1007/978-981-10-0471-1_15.

Diaz, A., Schöggl, J.P., Reyes, T. and Baumgartner, R.J. (2021), "Sustainable product development in a circular economy: Implications for products, actors, decision-making support and lifecycle information management", Sustainable Production and Consumption, available at: https://doi.org/10.1016/j.spc.2020.12.044.

Dokter, G., Thuvander, L. and Rahe, U. (2021), "How circular is current design practice? Investigating perspectives across industrial design and architecture in the transition towards a circular economy", Sustainable Production and Consumption, Elsevier B.V., Vol. 26, pp. 692-708, available at: https://doi.org/10.1016/j.spc.2020.12.032

Ellen MacArthur Foundation. (n.d.). "Learning Hub", available at: https://www.ellenmacarthurfoundation.org/explore.

European Circular Economy Stakeholder Platform. (n.d.). "Good practices”, available at: https://circulareconomy.europa.eu/platform/en/good-practices.

Fernandes, S. da C., Pigosso, D.C.A., McAloone, T.C. and Rozenfeld, H. (2020), "Towards product-service system oriented to circular economy: A systematic review of value proposition design approaches", Journal of Cleaner Production, available at: https://doi.org/10.1016/j.jclepro.2020.120507.

den Hollander, M.C., Bakker, C.A. and Hultink, E.J. (2017), "Product Design in a Circular Economy: Development of a Typology of Key Concepts and Terms", Journal of Industrial Ecology, available at: https://doi.org/10.1111/jiec.12610.

Kannengiesser, U., Williams, C. and Gero, J. (2013), "What do the concept generation techniques of triz, morphological analysis and brainstorming have in common", Proceedings of the International Conference on Engineering Design, ICED.

Kjaer, L.L., Pigosso, D.C.A., McAloone, T.C. and Birkved, M. (2018), "Guidelines for evaluating the environmental performance of Product/Service-Systems through life cycle assessment", Journal of Cleaner Production, available at: https://doi.org/10.1016/j.jclepro.2018.04.108.

Kravchenko, M., Pigosso, D.C. and McAloone, T.C. (2019), "Towards the ex-ante sustainability screening of circular economy initiatives in manufacturing companies: Consolidation of leading sustainability-related performance indicators", Journal of Cleaner Production, available at: https://doi.org/10.1016/j.jclepro.2019.118318.

Lüdeke-Freund, F., Gold, S. and Bocken, N.M.P. (2019), “A Review and Typology of Circular Economy Business Model Patterns", Journal of Industrial Ecology, available at: https://doi.org/10.1111/jiec.12763.

Maxwell, D. and Van der Vorst, R. (2003), "Developing sustainable products and services", Journal of Cleaner Production, available at: https://doi.org/10.1016/S0959-6526(02)00164-6. 
Moreno, M., de los Rios, C. and Charnley, F. (2016), “Guidelines for Circular Design: A Conceptual Framework", Sustainability, available at https://doi.org/10.3390/su8090937

Niero, M. and Kalbar, P.P. (2019), "Coupling material circularity indicators and life cycle based indicators: A proposal to advance the assessment of circular economy strategies at the product level", Resources, Conservation and Recycling, available at: https://doi.org/10.1016/j.resconrec.2018.10.002.

Ostertagová, E., Kováč, J., Ostertag, O. and Malega, P. (2012), “Application of morphological analysis in the design of production systems", Procedia Engineering, available at: https://doi.org/10.1016/j.proeng.2012.09.546.

Pieroni, M.P.P., McAloone, T.C. and Pigosso, D.C.A. (2019), "Configuring new business models for circular economy through product-service systems", Sustainability (Switzerland), available at: https://doi.org/10.3390/su11133727.

Reike, D., Vermeulen, W.J. V and Witjes, S. (2018), "Resources , Conservation \& Recycling The circular economy: New or Refurbished as CE 3 .0 ? - Exploring Controversies in the Conceptualization of the Circular Economy through a Focus on History and Resource Value Retention Options", Resources, Conservation \& Recycling, Elsevier, Vol. 135 No. November 2017, pp. 246-264. https://doi.org/10.1016/j.resconrec.2017.08.027

Ritchey (2011), "On the Formal Properties of Morphological Models", Wicked Problems - Social Messes, available at: https://doi.org/10.1007/978-3-642-19653-9_6.

Saidani, M., Yannou, B., Leroy, Y. and Cluzel, F. (2017), "How to assess product performance in the circular economy? Proposed requirements for the design of a circularity measurement framework", Recycling, available at: https://doi.org/10.3390/recycling2010006.

Schroeder, P., Anggraeni, K. and Weber, U. (2019), "The Relevance of Circular Economy Practices to the Sustainable Development Goals”, Journal of Industrial Ecology, available at: https://doi.org/10.1111/jiec.12732.

Shahbazi, S. and Jönbrink, A.K. (2020), "Design guidelines to develop circular products: Action research on nordic industry", Sustainability (Switzerland), available at: https://doi.org/10.3390/su12093679.

Stahel, W.R. (2010), The Performance Economy, 2nd Editio., Palgrave Macmillan.

Wiedmann, T., Lenzen, M., Keyßer, L.T. and Steinberger, J.K. (2020), "Scientists' warning on affluence", Nature Communications, available at: https://doi.org/10.1038/s41467-020-16941-y.

Willskytt, S. and Brambila-Macias, S.A. (2020), "Design guidelines developed from environmental assessments: A design tool for resource-efficient products", Sustainability (Switzerland), available at: https://doi.org/10.3390/SU12124953.

Zwicky, F. (1967), “The Morphological Approach to Discovery, Invention, Research and Construction”, New Methods of Thought and Procedure, available at: https://doi.org/10.1007/978-3-642-87617-2_14. 


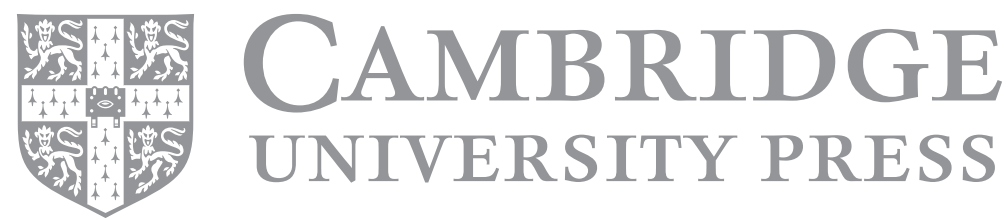

